\title{
衛星データによるアオサの繁茂状況の 把握に関する基礎的研究
}

\author{
武村 武1 ・ 落合 麻希子 $2 \cdot$ 内田 裕貴3 \\ 1 正会員 日本大学准教授 生産工学部環境安全工学科（干275-8575 千葉県習志野市泉町 1-2-1） \\ E-mail: takemura.takeshi@nihon-u.ac.jp \\ 2 学生会員 日本大学大学院 生産工学研究科土木工学専攻（干275-8575 千葉県習志野市泉町 1-2-1） \\ E-mail: cimk16005@g.nihon-u.ac.jp \\ 3 正会員 日本大学助手 生産工学部土木工学科（干275-8575 千葉県習志野市泉町 1-2-1) \\ E-mail: uchida.yuuki@nihon-u.ac.jp
}

\begin{abstract}
衛星データによるアオサの繁茂状況把握を目的に，谷津干潟にて UAV と衛星画像を用いて検討を行っ た. 2016 年 10 月 27 日と 11 月 4 日に UAVにより撮影された画像より, アオサの被度を算出した. その結 果，両日ともアオサの被度は $80 \%$ 程度であった。また，アオサの分光反射特性を検討した結果，525nm， $725 \mathrm{~nm}$ 付近に特徵が見られた。そこで, 衛星データから算出した NDVI を検討した結果, 10 月 27 日では, すべての算出地点でプラス值を示したが，11月 4 日では $90 \%$ 以上の範囲でマイナス值を示す事となった。 これらの差異は，水深との相関が高い事が確認され，その影響を考慮する事により衛星データによるアオ サ被度の把握が可能であることが示唆された。
\end{abstract}

Key Words : UAV, NDVI, Spectral Reflectance, Landsat

\section{1. はじめに}

近年, 全国的に内湾における藻類の発生が増加してい $ろ^{11,2)}$. この現象は，東京湾に接続する谷津干潟において も例外ではない3)。一般に, 藻場や干潟は, 水質浄化や 生物多様性の維持などの機能を有しており, その存在が 重要視されている ${ }^{4}$. 例えば，藻類は干潟に生息するカ 二や腹足類のホソウミニナなどの餌となり多様な生態系 を創出する一助となっている. また, 能登谷ら ${ }^{5}$ の調査 によれば, アオサ類は富栄養化した浅海域でも成長でき, 最適状況下では1日で2倍量になる種もあるとされ，その 成長の速度から，アオサ類による栄養塩類の吸収は他の 大型藻類と比較して水質浄化に大きく寄与寸ると報告さ れている. これらのことから, 様々な機能を有する藻類 の繁茂状況を把握することは, 水圈の環境評価をするう えで非常に重要である. 従来, 藻類の繁茂状況の把握に は現地調査を主に行われていたが，継続的にモニタリン グする必要があるうえに，ダイバーへの危険も懸念され ている，そのような問題点を解消す心゙く，近年では一度 に広域を観測できるリモートセンシング技術によるモニ タリングが着目されている6), リモートセンシングは, 広範囲にわたりデータを取得することが可能なうえ，物 質特有のスペクトル特性を把握し様々な調査に用いられ
ている技術である．しかしながら，水域に生息する植物 の繁茂状況を把握する手法は確率されておらず，種々な 検討が行われている8),9 .

本研究では，千葉県習志野市の東京湾最奥部に位置す る谷津干潟を対象とし，衛星データによるアオサの繁茂 状況把握を目的として, その前段階としてUAVによる空 撮ならびにFiled Spec Hand-Held(ASD社)を用いてアオサ の繁茂状況と分光反射特性を調查した。同時に, Ladnsat-7/8による衛星画像を用いてアオサの繁茂状況の 把握・検討を行った.

\section{2. 使用データおよび研究手法}

本研究の対象地とした千葉県習志野市の東京湾最奥 部に位置する谷津干潟は，1993年にラムサール条約登録 地となり, 主に水鳥の生息地として国際的に重要な湿地 帯と認定されている. 現地調査日は, Landsat7/8による観 測日を想定し2016年10月27日と11月4日を選定して調査 を行った．またアオサの特徵を把握するために，基礎研 究として野外放射計を用いて分光反射率の測定を行った. 
表-1 現地観測実地日一覧

\begin{tabular}{|c|c|c|c|c|}
\hline \multicolumn{2}{|c|}{ 撮影日時 } & アオサ被度 $(\%)$ & 水温 $\left({ }^{\circ} \mathrm{C}\right)$ & 潮位 $(\mathrm{cm})$ \\
\hline 10月27日 & 12時17分 & 80 & 24 & 108 \\
\hline 11月4日 & 12時49分 & 81 & 17 & 133 \\
\hline
\end{tabular}

表-2 Landsatによる観測日時一覧

\begin{tabular}{|c|c|c|c|}
\hline 衛星センサ & \multicolumn{2}{|c|}{ 観測日時 } & 潮位 (cm ) \\
\hline Landsat7 E TM & 10月27日 & 10時16分 & 77 \\
\hline Landsat8 0 L I & 11月4日 & 10時18分 & 170 \\
\hline
\end{tabular}

(1) UAV による空撮

現地におけるアオサの繁茂状況を把握するためDJI社 製PHANTOM3professionalのUAV(Unmanned Aerial Vehicle)を用いて空撮を行った. 空撮された画像から作成した オルソ画像をもとに，繁茂率の計測を行った。作成した オルソ画像を図-1, 図-2に示す. 作成したオルソ画像を Landsat-7/8により取得された画像と比較するために，谷 津干潟周辺の構造物を参照して位置合わせを行った。

\section{（2）アオサの分光反射特性の把握}

アオサによる反射特性を把握するために，現地におい てアオサの分光反射率の測定を行った．測定に使用した 器機は, ASD 社製の Filed Spec Hand-held(観測波長域 : 350nm-1075nm)である. 本機を用いて，陸上におけるア オサと干潟内でアオサの頂頭部(水中被度)での測定を行 った. 測定日時は 2016 年 10 月 18 日で, 太陽高度が最も 高いとされる午前 10 時〜午後 2 時の間に行った.

\section{（3） 衛星データによる解析}

植生の判断要素として用いられる正規化植生指標 NDVI(Normalized Difference Vegetation Index)を，アオサの 繁茂状況把握にも利用出来ないかを検討する. NDVI は，陸域に生息する植生の活性度を表しており，植物の 反射吸収特性を活かした指標であり，式(1)で示される.

$$
N D V I=\frac{(I R-R)}{(I R+R)}
$$

ここに，IRは近赤外域，Rは可視域赤の波長帯であり， 本研究で使用した衛星Landsat7ではband3， band4に， Landsat8ではband4, band5に相当する. Landsat7/8による 谷津干潟東部の画像を図-3, 図-4に示す. NDVIの值は-1 〜+1の範囲で表され, 值が高いほど活性度が高く, 低い ほど活性度が低いとされる。ここで, 衛星による撮影画 像の解像度は30mであるため, 算出されるNDVIは, 30m 四方内の代表值となる. なお, 表-1, 表-2に記載してい る潮位は，気象庁が公開している東京湾の潮位データで あり，東京湾平均海面(T.P.)を基準としている. また谷津 干潟自然観察センターへのヒアリングから, 谷津干潟と

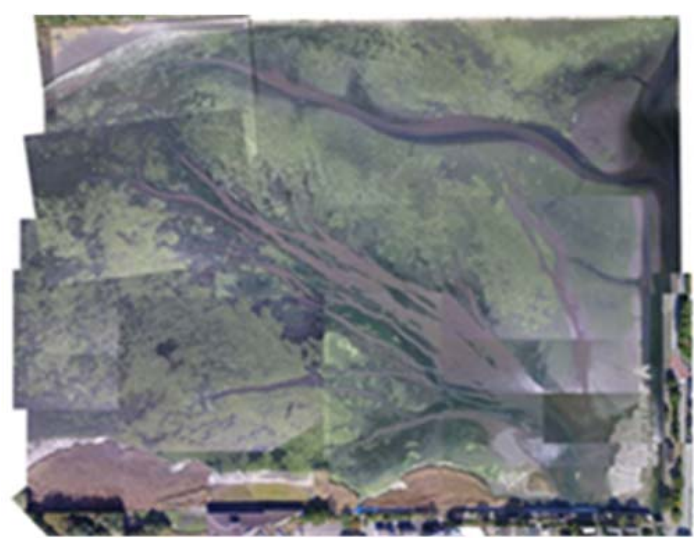

図-1 UAV による谷津干潟東部のオルソ画像 (2016年10月27日空撮)

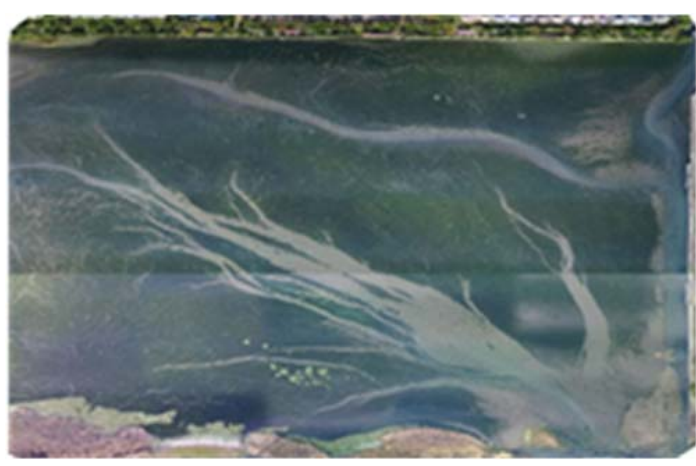

図-2 UAV による谷津干潟東部のオルソ画像 (2016年11月4日空撮)

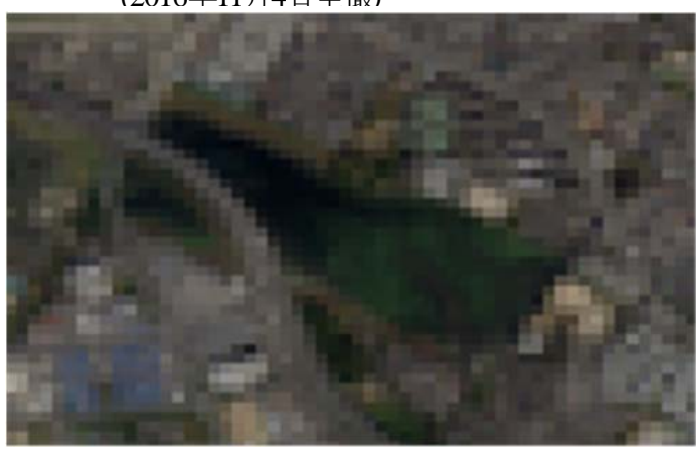

図-3Ｌandsat-7 ETM による谷津干潟東部 (2016年10月27日観測)

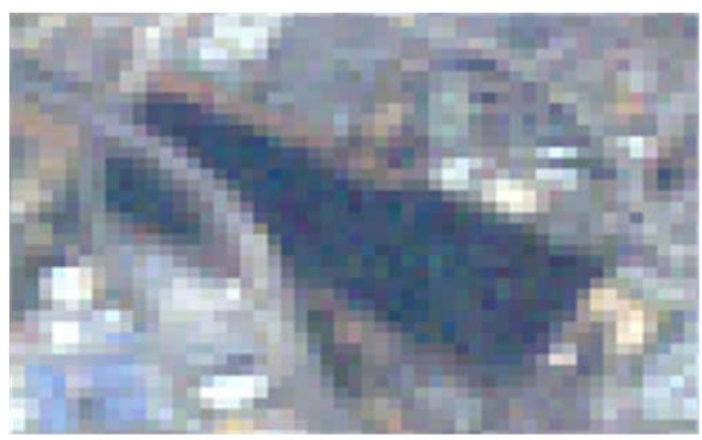

図-4Ｌandsat-8 OLIによる谷津干潟東部 (2016年11月4日観測)

東京湾の潮汐には約1.5時間の時間差がある点を付記す る. 


\section{3. アオサの分光反射率について}

アオサの分光反射特性を把握するために, Filed spec Hand-Heldを使用して, 分光反射率の測定を行った. 測定 日は2016年10月18日であり, 測定は陸上と水中の2つの状 況下において行った．いずれも測定時間は，太陽高度が 最も高いとされる日中の間に行った．陸上での測定結果 を図-5に示す．植生の分光反射特性は，可視域・近赤外 域において吸収帯・反射帯を持っており ${ }^{10)}$ ，今回の測定 結果は，その反射特性が明瞭に表れている. 次に水中で の分光反射率測定結果を図-6に示寸. 先の結果と同様に, 可視域・近赤外域において，微少ながらも特徵的な反射 率が得ることが出来た.

そこで，より詳細に特徵的な変化を見出すために 500nm〜 550nmの範囲, 625nm〜825nmの範囲における分 光反射特性曲線を1次微分により求めた ${ }^{11)}$. その結果を図 -7, 図-8に示す. 図-7に示した500nm〜550nmの波長領 域は可視光域(緑)に相当し，植生による反射率が高くな るとされている．陸上でのアオサと頂頭部(水中被度)の 結果から500nm〜 505nm, 545nm付近に特性が見受けられ た. 次に図-8に示した $625 \mathrm{~nm} \sim 825 \mathrm{~nm}$ の波長領域は近赤 外波長帯であり，植生の反射・吸収波長帯域となってい る. 陸上のアオサと頂頭部(水中被度)の反射率から, 765nm付近で反射・吸収の影響が見受けられた。 これら の結果から水面上の光の散乱・反射，波の影響を受けて いるが，今回対象とした谷津干潟内に繁茂するアオサの 特徽的な反射特性を得ることは可能であると示唆された。 そこで，この波長帯を使用しているNDVIなどの指標を 用いた繁茂域の把握も可能ではないかと考えられ，それ による評価を検討する.

\section{4. アオサ被度の検討結果}

\section{（1） アオサ被度の算出結果}

アオサによる分光反射特性の計測結果より, 可視光域 と近赤外域を用いた指標NDVIによる繁茂域の評価は可 能であると考えられた，そこで，現地においてUAVによ り撮影された画像から作成されたオルソ画像と，衛星デ ータを用いて評価を行った。UAVによる撮影日と Landsat-7/8の観測日を表-1，表-2に示す．はじめに，才 ルソ画像を用いたアオサ被度の算出方法について記述す る.UAVで撮影された画像をもとに作成されたオルソ画 像において，Landsatにおけるメッシュの状況を踏まえた 形で画像を分割し，メッシュごとにプラニメーターを用 いてアオサの被度を算出した。表-1に示寸様に全調査日 において，アオサ被度は80\%程度を示している。

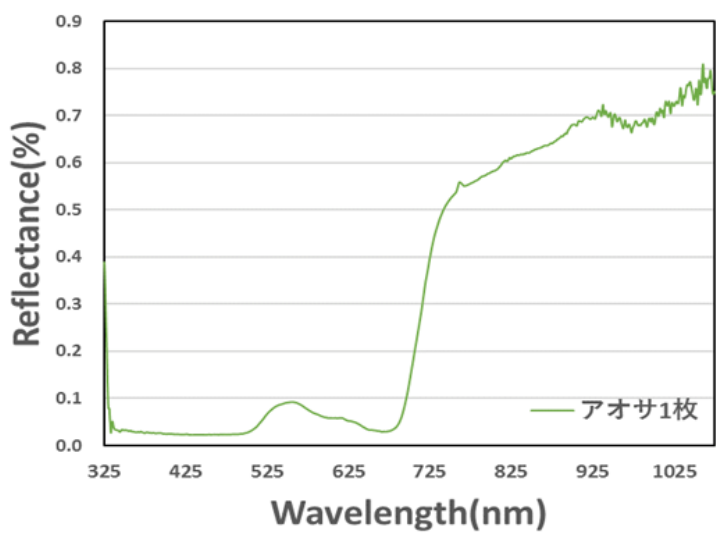

図-5 陸上におけるアオサの分光反射率

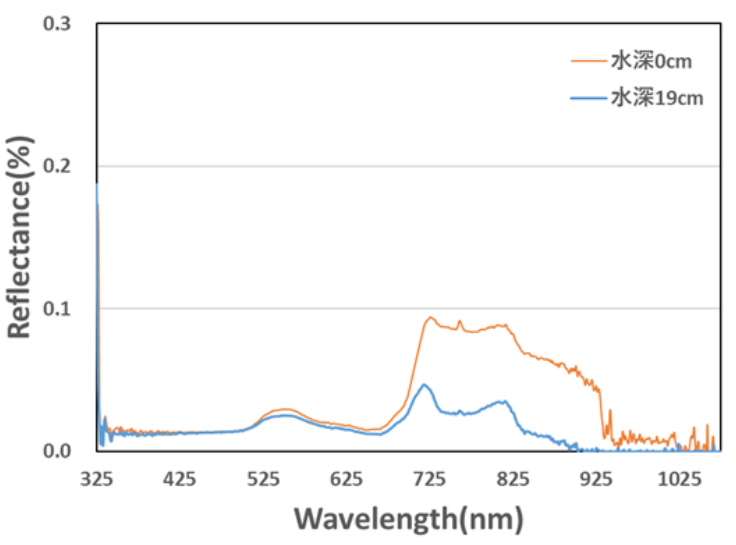

図-6 水中被度におけるアオサの分光反射率

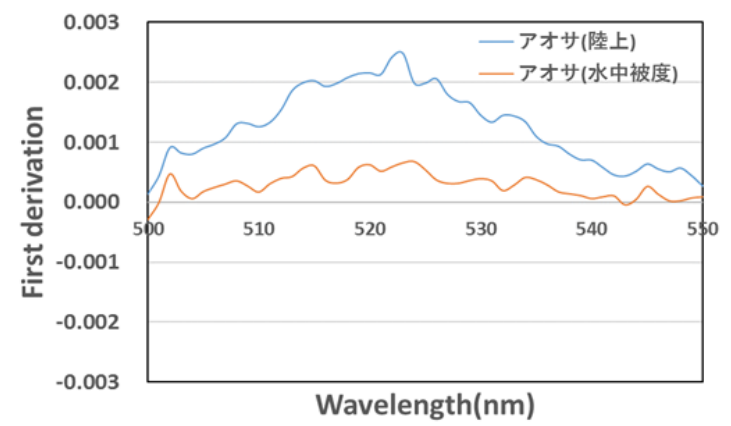

図-7 500nm〜550nmの範囲における分光反射特性曲線

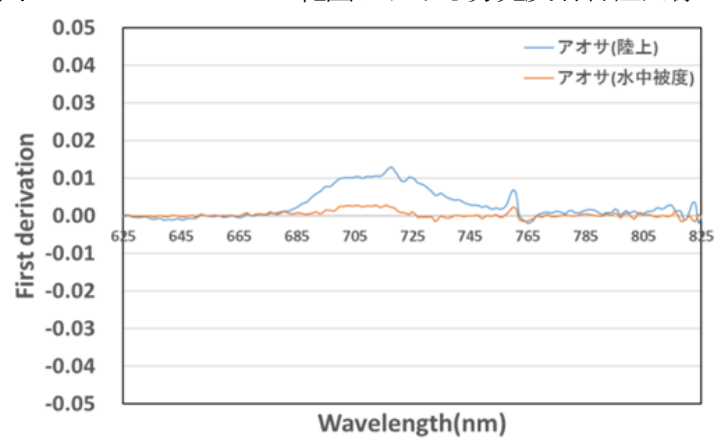

図-8 625nm〜825nmの範囲における分光反射特性曲線

一般的に，アオサの生育は水温が $20^{\circ} \mathrm{C}$ 環境下での生長 率が最も高く, 水温 $35^{\circ} \mathrm{C}$ 環境下では最も低い.ささらに 水温 $4^{\circ} \mathrm{C}$ 前後までの而性があることも報告されている ${ }^{12}$.

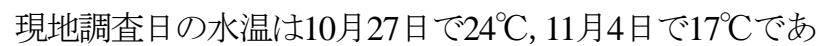
った.このことから，調査日の水温がアオサの生長に対 


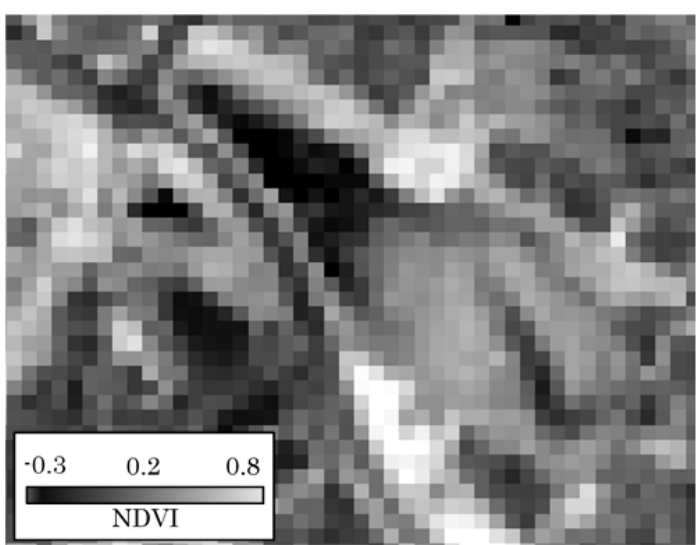

図-9ＮDVIの処理結果(10月27日,Landsat-8)

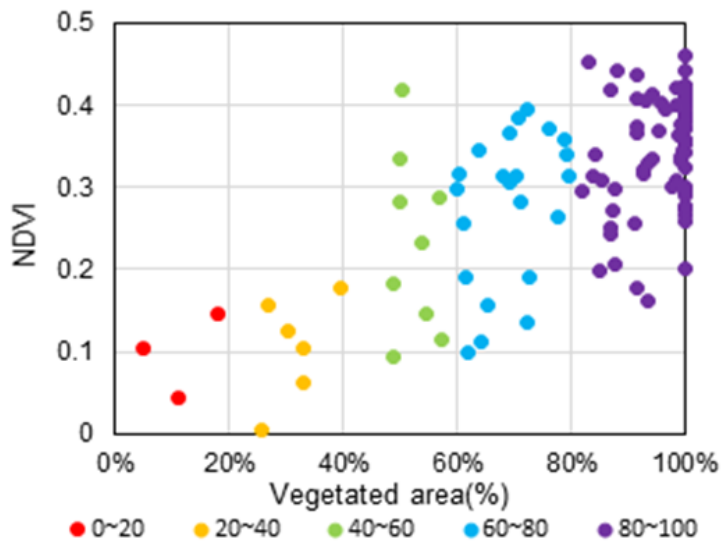

図-11 アオサ被度と NDVI の比較(10月 27 日)

して適温であったと考える.

\section{（2） NDVI とアオサ被度の比較}

本研究では，繁茂率を算出するためにNDVIを用いる こととした. NDVI (Normalized Difference Vegetation Index) は正規化植生指数と呼ばれ，植生の活性度を示す指標と なっている. Landsat-7 ETM, Landsat-8 OLIのデータより 算出した.

取得したデータを放射輝度から反射率へ変換する必要 があり，以下の式(2)〜(3)が提供されている ${ }^{13)}$.

$$
\begin{aligned}
& \text { Landsat-7 ETM } \\
& \qquad \begin{array}{l}
\rho_{\lambda}=( \\
\left.\left(G_{\text {rescale }} \times Q \text { cal }+B_{\text {rescale }}\right) \times \pi \times d^{2}\right) / \\
\quad\left(E_{U} N_{\lambda} \times \cos \theta_{s}\right)
\end{array}
\end{aligned}
$$

Landsat-8 OLI

$$
\rho_{\lambda}=\frac{\left(G_{\text {rescale }} \times Q \text { cal }+B_{\text {rescale }}\right)}{\cos \theta_{s}}
$$

ここで， $\rho_{\lambda}$ : 大気上端反射率， $G_{\text {rescale }}$ : ゲイン係数, Qcal : 量子化標準化画素值, $B_{\text {rescale }}$ : バイアス因子, $d$ : 地球と太陽の距離係数, $E S U N_{\lambda}$ : 大気圈外の平均太 陽放射照度， $\theta_{s}$ : 太陽頂点角となっている. 図 -9 , 図-10 に谷津干潟周辺の NDVI の処理結果を示寸。両画像の濃

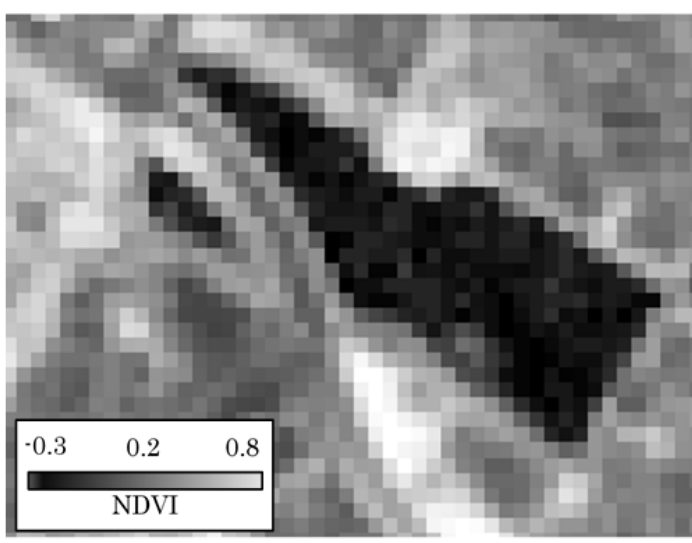

図-10ＮDVIの処理結果(11月4日,Landsat-7)

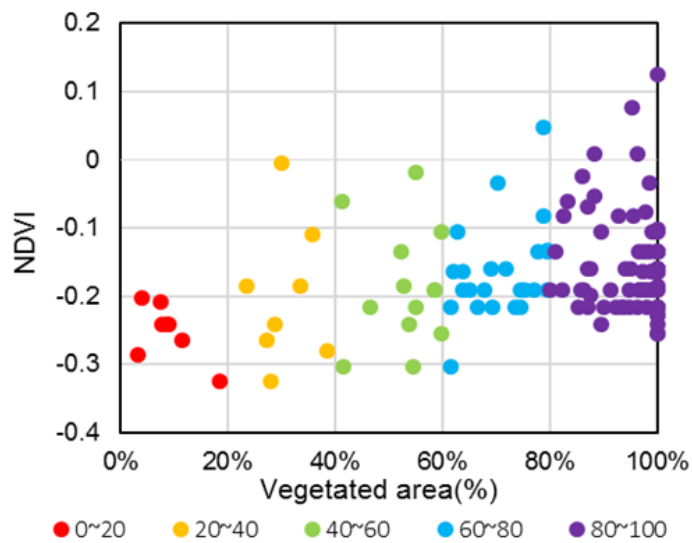

図-12アオサ被度と NDVI の比較(11月 4 日)

淡の違いは，NDVI が高いほど白く表示され，低いほど 黒くなっている. 次に, 算出した NDVI とアオサ被度を 比較した。比較した結果を図-11，図-12 に示す。図-11 より 10 月 27 日のデータではすべての繁茂範囲において プラス值となった. 一方，図-12 より 11 月 4 日のデー タでは，アオサの繁茂範囲の 9 割以上でマイナス值を示 した．両日とも，オルソ画像の結果からアオサの被度は 80\%程度で同様の值であったことを踏まえると，この差 異は潮位による影響が大きいと考えられる。

次に, オルソ画像から水表面に露呈しているアオサ(表 面被度)と，表面に水がかかっているアオサ(水中被度)を 区分し，衛星画像から，表面被度と水中被度における NDVIを算出した．その結果を図-13，図-14 に示す．表 面被度はアオサの被度の大小にかかわらず，プラスの值 を示すことが確認された，一方，水中被度はアオサの被 度が100\%であってもほとんどの地点でマイナス值を示 す結果となった。 これは，水表面における反射の影響が 大きく，無視できないことを示している。

次に，水深の違いによる水中被度を検討した，算出結 果を図-15，図-16に示す，縦軸は，アオサが水中にある 場合のNDVIを示している．横軸は東京湾平均海面(T.P.) を基準（ゼロ）とした水深（マイナスが水中）である. この結果から，10月27日撮影のデータでは，水中被度に 


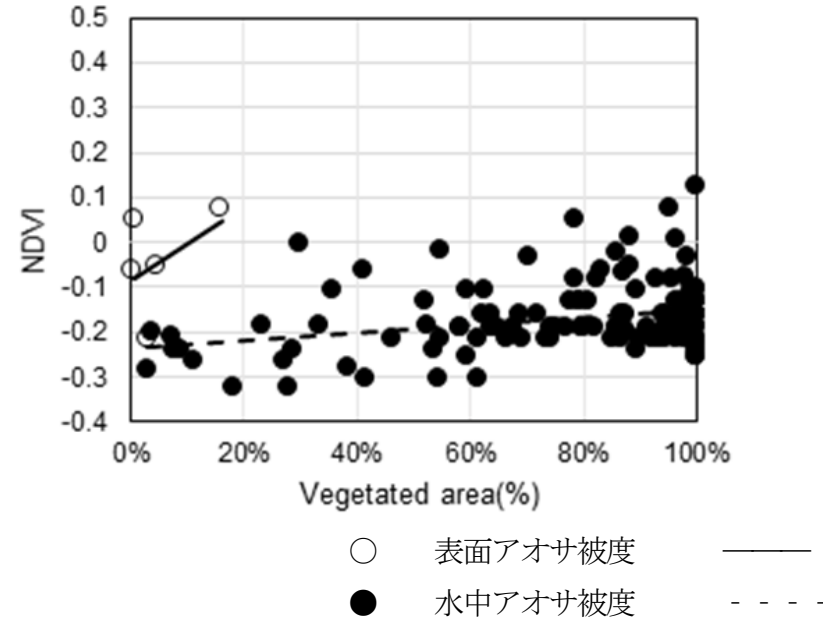

図-13 アオサ被度とNDVIの比較(10月27日)

おいてもプラス值が確認されているが, 11月4日撮影のデ ータでは，ほとんど確認されない，また，水深が浅くな るとNDVIが大きくなっていることもわかる.

谷津干潟におけるアオサに関する調査は多く行われ ており，一年を通してアオサが生息していると報告され ている ${ }^{12), 14)}$ ．しかし，水中におけるアオサ群落の生育状 況は報告されていない，また，アオサの生態量に関する 調査は，谷津干潟を含めた浅海域や池などで多く行われ ている. しかし，調査地点ごとに現存量の值の差が大き 、15),16)，加えて，アオサの形状に関する報告もされてお り，大きいものでは長径 $3 \mathrm{~m}$ 以上に達寸る ${ }^{17)}$ 。しかし，水 中におけるアオサ群落の状況はわかっていない.

ここで，10月27日と11月4日の潮位の差は100 cm以上あ ることから，アオサは水底からある程度の高さまでで群 落を形成しており，潮位の差により水表面からアオサ頭 頂部までの距離に差が出たため，前述のような結果にな ったと推測される. しかし，水表面とアオサ頭頂部の距 離に関する観測結果等がないため，今後さらなる検討が 必要だと考えられる.

最後に本研究は衛星データによるアオサの繁茂状況 把握を行うための評価式の提案を念頭に置き検討を行っ た. 今後の評価式の構築にあたり, 潮位(水深)の影響を 十分に考慮すればアオサの繁茂状況把握は可能であるこ とが示された。

\section{5. まとめ}

本研究は，谷津干潟内に繁茂しているアオサの繁茂状 況を把握するため, 現地による調査ならびに UAV, 衛星 データを用いて検討を行った.

現地調査では，アオサの分光反射特性を見出すことが できたがアオサは陸域に生息する植物ではなく海面下に

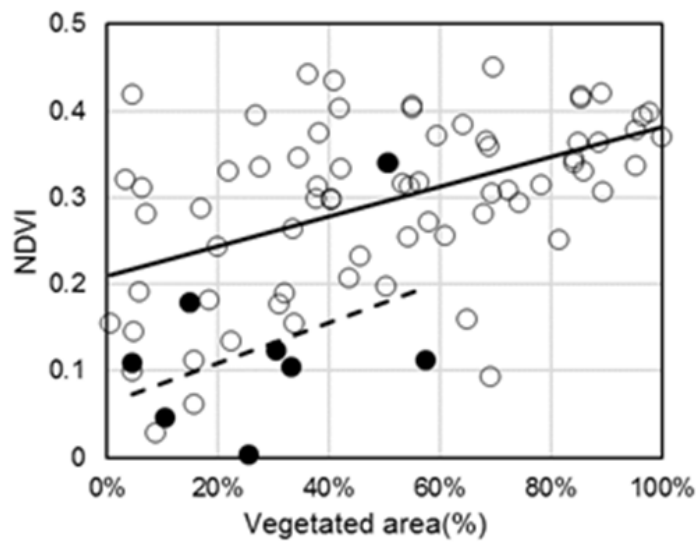

近似線(表面アオサ被度)

近似線(水中アオサ被度)

図-14アオサ被度とNDVIの比較(11月4日)

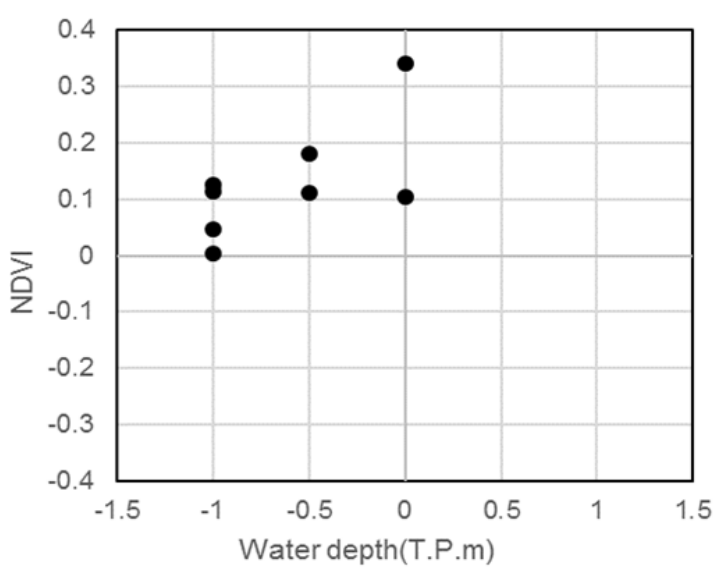

図-15アオサ被度とNDVIの比較(10月27日)

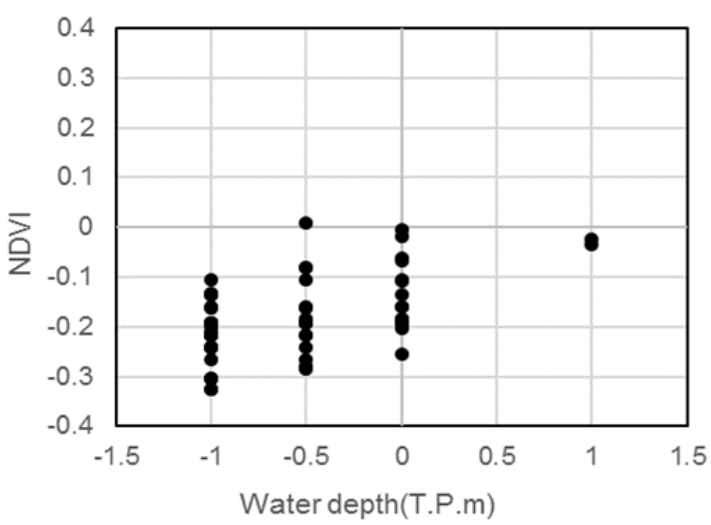

図-16アオサ被度とNDVIの比較(11月4日)

生息する水生植物なため，今後の調査では光の散乱，波 の影響などを考慮する必要がある。 また，アオサ被度と NDVIを比較した結果，潮位差が大きく影響しているこ とが示唆され，今後の評価式の構築にあたり，潮位の時 間変化を考慮しなければならないと考えられる.

謝辞

本研究を行うにあたり，千葉県谷津干潟観測センター の職員の皆様にご協力をいただきました。ここに記して 
感謝の意を表します.

参考文献

1）工藤教勇, 巟玉真史, 徳永貴久, 松永信博 : 干潟に おけるアオサの消長が生物生息環境に及ぼす影響, 海岸工学論文集 Vol. 50，P1081-1085， 2003.

2）寺脇利信，吉田吾郎，内田基晴，浜口昌巳 : 瀬戸内 海の干潟・藻場の現状と順応的管理, 海洋開発論文 集, Vol. 21, P83-88, 2005.

3）矢部徹，石井裕一，天野佳正，立本英機 : 谷津干潟 のグリーンタイドに関する研究，日本陸水学会大 73 回大会, 2008.

4）環境省 第一回環境・生態系保全活動支援制度検討 会. 資料 3 干潟・藻場の機能. 2010 .

5）能登谷正浩: 海藻類による環境修復, 日本藻類学会 創立 50 周年記念出版，92-94， 2002.

6）宮野忠文，佐野誠，長谷川浩治，馬場祥宏，小黒岡 成, 相田聡, 千葉良三: リモートセンシング画像に よる藻場分布把握技術の開発（第 2 報），広島県立 西部工業技術センター研究報告, No. 49, pp. 12-15, 2006.

7）ルイ ソチェー, 作野裕司 : 衛星 Terra/ASTER デ ータを使った吉名干潟における藻場モニタリング, 水工学論文集, Vol. 52, 2008.

8）沖一雄，安岡善文，田村正行 : 高濃度水域における 水質リモートセンシング，日本リモートセンシング 学会誌 Vol. 21, No. 5P449-457, 2001.

9）古海 忍, 林 礼美, 塩野 由美子, 村松 加奈子, 藤原 昇 : Landsat/MSS，TM データを使ったパ ターン展開法による関西地域の植生変動解析, 日本
リモートセンシング学会誌 Vol. 17 No. 4, pp. 34-49, 1997

10）伊藤健吾，大槻恭一，神近牧男 : 分光反射特性を用 いた植生の植被率と活性度の分離，日本リモートセ ンシング学会誌, Vol. 16, No. 4, pp. 41-49, 1996.

11）関岡信一，石川大太郎，野呂忠秀，石黒悦爾：リモ 一トセンシングによる藻場の現存量推定手法に関 寸る基礎的研究, 日本リモートセンシング学会, Vol. 28 No. 4, pp. 342-349, 2008.

12）矢内栄二，本永麻衣子，藤原誠司，室山結実 : 東京 湾奥部の谷津干潟におけるアオサとノリの繁殖特 性, 土木学会論文集 B2, Vol. 66, No. 1，1081-1085, 2010.

13）岡本勝男:Landsat データのメタ情報を用いた分光 放射、反射率、輝度温度自動変換プログラムの開発, システム農学会，31(3)81 90，2015.

14）矢部徹，石井裕一，井元辰哉，五明美智男 : 谷津干 潟におけるアオサの繁茂特性に関する現地調査, 海 洋開発論文集，第 23 巻， 2007 .

15）芳村碧，矢持進 : 大阪南港野鳥園北池におけるグリ ーンタイドの季節的変遷と原因海藻ミナミアオサ の低塩分・干出而性に関する研究，土木学会論文集 B2, Vol. 67, No. 2, 2011, I_1136-I_1140.

16）環境省 : 平成 24 年度第 2 回国指定谷津干潟鳥獣保 護区保全事業検討会 配布資料.

17）愛知県蒲郡市：アオサ活用に関する調查報告書, 2011.

(2017.2.2 受付)

\section{FUNDAMENTAL STUDY ON ULVA SPP. MONITORING BY SATELLITE DATA IN YATSU TIDAL FLAT}

\section{Takeshi TAKEMURA, Makiko OCHIAI, Yuuki UCHIDA}

The satellite data and UAV (Unmanned Aerial Vehicle) was used to measure the vegetated area of Ulva spp. in YATSU tidal flat. The vegetated areas of Ulva spp. on 27 Oct. 2016 and 4 Nov. 2016 were measured from the image taken by UAV and its vegetated area were around $80 \%$ on both day. And characteristics of spectral reflectance of Ulva spp. were almost same as that of land green plant. Therefore, NDVI indicated a positive value at all area on 27 Oct. however, it indicated a negative value in the range over $90 \%$ on 4 Nov. It was confirmed that these differences strongly correlate with water depth. So, it was suggested that it is possible to evaluate the vegetated area of Ulva spp. by satellite data by considering the influence of water depth. 